\title{
The importance of international experience for Romanian students in establishing career priorities
}

\author{
Lavinia BUTUM \\ The Bucharest University of Economic Studies, Bucharest, Romania
}

\begin{abstract}
Romanian students' appreciation towards international experience has been increasing as the number of students involved in international programs has been rising year by year. Also, students' expectations upon graduation are more related to finding a good job, usually in multinationals. Studies conducted in Romania (Frunzaru et al., 2013) and (Nicolescu and Păun, 2009) showed that students give great attention to the skills they acquire after completing various programs, often their choices being focused on several successful areas and international programs. The joint projects of several universities and governmental authorities in Romania have aimed to develop the international dimension of education (IEMU, 2015). The results of implementing those projects could be revealed by students' perception of international competences gained by curricula or international exchange programs. The purpose of this paper is to analyze the dynamics of Romanian and European graduates' satisfaction with international experience and extracurricular resources accessed during university courses. Also, the article will analyze the dynamics of graduates' career priorities in accordance with the skills provided upon graduation. The data are selected from Trendence Graduate Barometer - Romanian Edition and the analysis establishes relevant conclusions regarding the young Romanian graduates' need to develop, in comparison with European graduates from 5-year statistic data (2012-2016). The conclusions include a comparison of international exchange programs and career priorities expectations among Romanian and other European graduates. Also, the paper will draw new research directions regarding students' need for specialization especially in gaining international competences.
\end{abstract}

Keywords: High- skilled employees, Higher Education, International mobility, International competences, Labour market, Learning process

Please cite the article as follows: Butum, L. (2017), "The importance of international experience for Romanian students in establishing career priorities", Management \& Marketing. Challenges for the Knowledge Society, Vol. 12, No. 1, pp. 155-170. DOI: 10.1515/mmcks-2017-0010.

\section{Introduction}

This paper approaches students' international experience from a career perspective. First, the literature review chapter will examine the international competences gained in Romanian universities through curricula and international mobility programs and will then analyze the connections between international competences and graduates' future career as recognized in students' need to develop.

The article highlights the dynamics of Romanian and other European students' appreciation for international experience as provided by their university and will compare the university performance in terms of importance versus satisfaction as perceived by students. Also, the analysis of students' need to develop and their future career will show the increase in demand for international competences, in view of obtaining a job in an international environment along with 
the interest to continue the studies abroad or to get involved in voluntary activities in order to gain practical competences. The analysis will show the gap between importance and satisfaction in the evaluation of university performance for different topics such as competences, international activity (exchange programs and university partnership), extracurricular activities and additional services (events, careers advice, job exchange).

\section{Literature review \\ International competences gained in Romanian universities through curricula or international mobility programs}

The scientific literature recognizes (Qiang, 2003; Rizvi, 2007) that the demand for intercultural communication, dialogue and negotiation lead to a change in curriculum for better insurance of international competence. This competence is achieved through both curricula and international experience and is seen as a set of other skills such as adaptability, flexibility, tolerance, responsibility, communication in multicultural teams and confidence. The international competence also known as global competence is associated with the capacity to analyze intercultural issues from multiple perspectives. Students' opinion on this set of skills is usually positive, many of them considering that the international competence is essential for international business (Rizvi, 2007). The intercultural competence is seen as "the ability to communicate effectively and appropriately with minimal loss or distortion", "the ability to attain compliance and to obtain cooperation with others" (Fantini, 2000, p. 27) and is easily achieved during international exchange programs where students can interact with many people from different cultures and are involved in diverse projects within multicultural teams.

In Romania, the global process of internationalization of higher education has led to a change in both curricula and the development of international mobility programs. On the one hand, the Romanian national policies concerning education are adapted to the European policies in order to better coordinate the Higher Education Institutions, and, on the other hand, universities have aimed at providing human capital with those qualifications, knowledge and abilities that are relevant for increasing productivity in a globalized economy. Thus, at regional level, Romania has swiftly adapted and integrated the European reforms in the process of internationalization of higher education. This was not only a direct consequence of state policy for European integration but it was also a natural response to students' demands for international competences and international learning opportunities.

Through active participation as members of international associations, universities have established as their main goal the improvement of the quality of services offered to Romanian and foreign students. Also, universities' cooperation with students' associations, non-governmental associations or other institutions have aimed to ensure good visibility of the universities at national or international level. These actions are part of an assumed medium-term strategy for increasing academic competitiveness. Between them, the move towards international activities has helped universities to develop the institutional strategies frames for academic internationalization (ASE- International Strategy, 2015). 
The development of internationalized curriculum and the development of new teaching and learning tools including distance learning are part of home internationalization concept. The concept of home internationalization includes a variety of activities such as the revision of course content, the use of foreign languages in teaching and learning process and the organization of extracurricular activities with an international perspective for students (Nicolescu, 2014). A recent study dedicated to modern learning tools and distance learning (Găitănaru, 2016) has revealed that the new knowledge process has improved students' cognitive results. Throughout the learning activities students attribute different degrees of importance to the entire learning process based on their perceived usefulness deciding to choose those actions and activities that rely on the purpose, objectives and most importantly the needs they may have. Thus, by using the modern learning tools, the students gain useful competences related to the ability to work under pressure, social competency, responsibility and flexibility.

From the opposite perspective, the internationalization abroad includes mobility of students, teachers, staff and curriculum (usually under agreements of international exchange programs) (Knight, 2004). A study which analyzed the employment of former Erasmus students (Teichler and Janson, 2007) showed that their international experience was viewed as having had a positive influence on their later employee work tasks. Moreover, the study revealed that the former Erasmus students are, to a high degree, engaged in jobs that are related to international activities or they are working in an international environment.

A different, curriculum oriented approach, synthesized a wide typology of internationalized curricula. Thus, OECD cited in Van der Wende (1997, pp. 56-57) suggests that there can be curricula:

1. with an international subject

2. in which the traditional/original subject area is broadened by an internationally comparative approach

3. which prepare students for international professions

4. in foreign languages or linguistic which explicitly address cross cultural communication issues and provide training in intercultural skills

5. which are interdisciplinary covering more than one country

6. leading to internationally recognized professional qualifications

7. leading to joint/ double degrees from different countries

8. of which compulsory parts are taught at institutions abroad

9. in which the content is especially designed for foreign students.

From all these curricula typologies, in Romania, research articles and the higher education regulations provide information about the number of master programs learned and taught in foreign languages. Thus, in the academic year 20112012 , the number of master programs taught in foreign languages represented a variation between $5 \%$ and $22 \%$ from the total of master programs in Romanian universities, and in the academic year 2016-2017 the variation represents $10-34 \%$ from the total of master programs (Nicolescu, 2014; GD, 2016). It can be concluded that in only 5 academic years the Romanian universities almost doubled the number of master programs in foreign languages. 
Studies conducted in Romania (Nicolescu, 2014) have shown that mobility is seen as the main form of internationalization of Romanian higher education system. The number of Romanian students involved in international exchange programs (e.g. Erasmus+) increased gradually from 3.494 in academic year 2005-2006 to 4.578 in 2011-2012 (Nicolescu, 2014; EC, 2013). Also, it could be mentioned that in the academic year 2013-2014, from the total of 7.169 Erasmus students that took part in an intensive language courses (in languages that are not widely used), 15.9\% were Slovenians, followed by Romanians with 12.2\% (EC, 2015). This interest for learning foreign language has increased lately and represents the first step for achieving other international competences.

In order to explain the link between the internationalized curriculum and the international exchange programs, it could be concluded that even if they involve different framework approaches, both of them have strong connections with providing intercultural and international skills and ensure students' preparation for international professions.

\section{Romanian students' need to develop for future career}

Generally, higher education researches show that students' access to extracurricular resources and international experience are considered important for acquiring international skills necessary for successful careers as future employees and entrepreneurs (Nicolescu, 2014; Altbach and Knight, 2007). Thus, communication skills and teamwork developed in international programs or accomplished through the internationalized curricula are considered useful for understanding and getting involved in different work projects. Consequently, universities and employers have experienced the need to identify those skills that will help students become competitive at national and international level in order to bring their contribution to the global work environment (Qiang, 2003).

Along with the interest of students for international education programs, the workforce has been interested in accessing highly-paid jobs in multinational companies. Evidence suggests that the vast majority of students that have been participating in international programs has a better chance of being hired in multinational companies. Apart from that, it seems that the communication skills developed during an international program have been helping the young graduates to get a job in a multinational environment (Altbach and Knight, 2007).

Comparative studies conducted in Romania (Nicolescu, 2011; Nicolescu and Dima, 2010) show that Higher Education Institutions need to meet the expectations of their students by delivering superior quality services. The tendency to analyze the quality of academic programs by applying satisfaction questionnaires on students is based on a great need to adapt the curricula and the skills provided to the change in academic environment. Even more, in the broader context of higher education internationalization, the analysis of quality services provided could be seen as a result of increasing competition in higher education.

In this regard, being competitive means on the one hand being proactive in satisfying students' demands as direct clients, and on the other hand keeping up with employers' request for skills and competences as indirect clients. Furthermore, 
the skills and competences should be in accordance with the requirements of the labor market to maintain the fragile balance between supply and demand for welltrained work force (Nicolescu and Păun, 2009). The research also showed that Romanian universities are good at providing very good theoretical skills, but have poorer performance in the development of practical skills. Analyzing companies' criteria for the selection of employees, the study mentioned that the employers usually prefer graduates with previous organizational experience with both technical performance and intercultural skills.

In Romanian students' view, international skills gained during an international program helped them become confident in their abilities and competences. They also saw an increase in their ability to understand more easily the theory, because they had the opportunity of internships in a multicultural environment. Even more, an international experience gave students access to a desired job anywhere in the world (Udrea and Ştefăniţă, 2016).

Analyzing volunteering as extracurricular activity, Matthews et al., (2009) have identified that this type of activity developed in home country or abroad has direct implication on future employability because of the rapid gain of valuable skills necessary for integration into the labor market. This type of skills is usually related to interpersonal and practical abilities and comes to complete the theoretical abilities.

In a nutshell, the competences needed for the future career are achieved through curricula content, extracurricular activities in home country or abroad and international exchange programs. The global mobility of people and knowledge has led to expansion of international mobility programs, in recent years. Also, the development of multinationals has led to an increased need for competences that require teams solving problems, communication in multicultural environment and flexibility to adapt to complex issues and projects (Sawyer and Sprinkle, 2003).

\section{Methodology}

The paper aims to analyze the results of 5-year statistic data from Trendence Graduate Barometer (Trendence Institute, 2012, 2013, 2014, 2015, 2016). Trendence is a European research institute specialized in employer branding, personal marketing and recruiting. Also, this institute provides information regarding students' perception on achieved skills upon graduation, analyzing collections of data from universities across Europe. The dynamics of collected data in years 2012-2016 is shown below:

Table 1. Survey participants in Trendence Graduate Barometer

\begin{tabular}{|c|c|c|c|c|c|c|c|c|c|c|}
\hline \multirow{3}{*}{\begin{tabular}{|l|} 
Number of \\
survey \\
participants - \\
graduates
\end{tabular}} & \multicolumn{5}{|c|}{ Europe } & \multicolumn{5}{|c|}{ Romania } \\
\hline & 2012 & 2013 & 2014 & 2015 & 2016 & 2012 & 2013 & 2014 & 2015 & 2016 \\
\hline & 343.796 & 317.617 & 301.949 & 281.749 & 293.541 & 9.302 & 11.652 & 7.376 & 7.413 & 12.893 \\
\hline
\end{tabular}

Source: Trendence Graduate Barometer - European edition years 2012, 2013, 2014, 2015, 2016.

Starting from the above information, this study aims to structure and synthesize the data in order to analyze students' interest for international and 
practical experience and to establish their interest for international competences. Afterwards, the analysis will establish students' appreciation for lectures in a foreign language, applied case studies, university research projects and will highlight the students' interest for international skills. In addition, the paper will analyze the dynamics of students' appreciation for interpersonal skills gained through curricular or extracurricular activities in Romanian and European universities.

\section{Findings}

Students' appreciation for university-provided skills in accordance with labor market demand

Analyzing the dynamics of Romanian students' appreciation on provided skills (Table 2), the level of satisfaction varies from $43.2 \%$ of respondents' number in 2012 to $54.2 \%$ in 2016, surpassing the European average, which was relatively constant in the last 5 years (44.6\% in 2014, 43.7\% in 2016). Also, the data shows that in 2016, 25\% of Romanians respondents were discontent with the skills provided by their university. In the same year, in other European countries, 30.9\% of respondents showed disagreement with skills provided upon graduation, the highest negative opinion regarding skills' connection with labor market in the last 5 years. This could be interpreted as a high demand for performance in term of professional and practical skills necessary for the labor market as will be seen in Table 3. The number of respondents with no clear opinion on provided skills decreased in Romania from the highest level of $39.3 \%$ in 2014 to $20.8 \%$ in 2016. The process is similar in other European countries, the number of students with no opinion on their achieved skills descending from 33.3\% in 2013 to $25.3 \%$ in 2016. Thus, the students have become more focused on achieving skills in accordance with labor market demands and their expectations upon graduation are more related to finding a good job than just obtaining a diploma but with no certainty for future employment.

Table 2. Students' appreciation of skills necessary for the labor market

\begin{tabular}{|l|c|c|c|c|c|c|c|c|c|c|}
\hline $\begin{array}{l}\text { Appreciation for } \\
\text { university-provided } \\
\text { skills necessary for } \\
\text { labor market }\end{array}$ & \multicolumn{4}{|c|}{ Europe } & \multicolumn{6}{c|}{ Romania } \\
\hline Agreement & 2012 & 2013 & 2014 & 2015 & 2016 & 2012 & 2013 & 2014 & 2015 & 2016 \\
\hline Disagreement & $49.2 \%$ & $44.7 \%$ & $44.6 \%$ & $45.2 \%$ & $43.7 \%$ & $43.2 \%$ & $59.1 \%$ & $45.5 \%$ & $42.8 \%$ & $54.2 \%$ \\
\hline No opinion & $23.2 \%$ & $21.7 \%$ & $23.3 \%$ & $23.9 \%$ & $30.9 \%$ & $29 \%$ & $14.4 \%$ & $15.2 \%$ & $20.7 \%$ & $25 \%$ \\
\hline
\end{tabular}

Source: Trendence Graduate Barometer - European edition years 2012, 2013, 2014, 2015, 2016.

Students' appreciation of university performance in terms of importance and satisfaction

The selected items for analyzing the dynamics of European and Romanian students' appreciation of university performance are competence-centred. Thus, for this analysis, the comparison between importance and satisfaction on university quality services and teaching performance will be focused on relevant information 
regarding professional and practical competences, international programs provided for students, university assistance for students in finding a job, as presented in Table 3 and Graphics 1, 2 and 3.

Starting with students' evaluation of professional competences, the data shows that in the last 2 years both Romanian and European students have considered that technical skills are very important for their future career. Thus, in years 2015 and 2016, 91.8\%, respectively 91.9\% of Romanian respondents perceived an increased need for professional competences. In European universities, in 2015 and $201688.7 \%$ of respondents, respectively 88.6\%, considered that professional competences are very useful for future employability. It could also be mentioned that in previous years 2012-2014 Romanian and European students' opinion on university performance in providing professional skills was almost constant and there was no significant difference (in 2012, 68\% of European respondents and respectively $68.4 \%$ of Romanian respondents recognized the importance of professional competence). In terms of students' satisfaction versus importance of provided technical competences, the data shows that there is a gap ranging from $0.4 \%$ to $10.2 \%$ in the last 5 years in Romanian students' perception of importance and satisfaction with the competences achieved in university. In Europe, the gap is less evident (5\% in 2015) and in the years 20122014 the students were even more content with the provided skills than they recognized the importance of the competence.

When it comes to analyze the practical relevance of the content of study, the students recognize the importance of practical competences they achieve upon graduation, in late years the appreciation increasing in Romania from $68.9 \%$ in 2012 to $81.1 \%$ in 2016, becoming closer to the European average of $78.2 \%$ in the same year. The data also shows a big gap between the recognition of practical relevance of the content of study and the satisfaction with the practical skills provided. Thus, in Romania the difference varies from 23.1\% in 2012 to $21.5 \%$ in 2016, showing students' discontent with the practical skills provided by their university. In Europe, the difference between the importance and satisfaction with provided skills as perceived by students varies from $2.4 \%$ in 2012 to $13.7 \%$ in 2016 . The results demonstrate that Romanian universities are more centered towards providing professional competences, than towards satisfying students' demands for practical competences.

As the literature review recognizes, the students are usually content with the international experience gained during their university studies. The data from Table 3 shows that there is no significant difference between the importance and satisfaction with students' international skills provided through international exchange programs. Still, there is a difference in perception between Romanian students and their European colleagues. Thus, Romanian students' appreciation of international competences has a major importance, rising from $56.8 \%$ in 2012 to $68.8 \%$ in 2016, compared to other European students, which increased from $46.2 \%$ in 2012 to $55.1 \%$ in 2016.

Analyzing the university provided assistance for students in finding a job, the available information point out that the consultation services are considered 
important by $62 \%$ of Romanian students in 2016 , the number growing from $45.8 \%$ in 2012, but the satisfaction for these services decreased from $61.1 \%$ in 2012 to $36.3 \%$ in 2013, and then grew slowly at $45.1 \%$ in 2016. In other European countries, students' evaluation shows a relatively constant opinion, from 2013 to 2016, the gap between satisfaction and importance of provided services for career consultation being less than 3.5\%. This proves either poor services for career counselling in Romanian universities, or a special need of Romanian students for receiving extra services in job advice, job exchange and other extracurricular activities that involves university collaboration with employers. The evaluation of job and career fairs in Romania as perceived by students is similar to assistance services in future career provided by universities. Thus, in 2015 , only $53.5 \%$ of Romanian respondents showed their satisfaction with job and career fairs even if $63.2 \%$ considered that those activities organized by universities and companies are very useful for finding a job during student life as part time activities or after graduation. In other European countries, students show their appreciation for job and career fairs organized by their universities (58.3\% of respondents in 2016), surpassing the recognized importance of job fairs $(50.8 \%$ of European students in the same year).

These results also show that Romanian students consider that universities need to develop collaboration with companies in order to integrate the theory with work experience. Thus, the importance of integrated work experience has grown from $59.9 \%$ in 2012 to $71.7 \%$ in 2016 . This trend is also available for other European universities, where students' appreciation for the importance of integrated work experience has grown from 43\% in 2012 to $63.3 \%$ in 2016 . In terms of satisfaction, the Romanian respondents are less content, the gap between importance and satisfaction being $20.2 \%$ in 2016. The results, also point to the fact that Romanian students feel the deficiency in their university's long-term collaboration with private companies.

Table 3. Students' appreciation of university performance

\begin{tabular}{|c|c|c|c|c|c|c|c|c|c|c|}
\hline \multirow{2}{*}{$\begin{array}{l}\text { Evaluation of } \\
\text { university } \\
\text { performance: }\end{array}$} & \multicolumn{5}{|c|}{ Europe } & \multicolumn{5}{|c|}{ Romania } \\
\hline & 2012 & 2013 & 2014 & 2015 & 2016 & 2012 & 2013 & 2014 & 2015 & 2016 \\
\hline \multicolumn{11}{|l|}{$\begin{array}{l}\text { Professional } \\
\text { competence }\end{array}$} \\
\hline Importance & $68 \%$ & $59 \%$ & $65.8 \%$ & $88.7 \%$ & $88.6 \%$ & $68.4 \%$ & $69.4 \%$ & $67.6 \%$ & $91.8 \%$ & $91.9 \%$ \\
\hline Satisfaction & $71 \%$ & $69.8 \%$ & $70 \%$ & $83.7 \%$ & $84.9 \%$ & $68 \%$ & $68.2 \%$ & $71.7 \%$ & $81.4 \%$ & $88.4 \%$ \\
\hline \multicolumn{11}{|l|}{$\begin{array}{l}\text { Practical relevance } \\
\text { of the content of } \\
\text { study (practical } \\
\text { competences) }\end{array}$} \\
\hline Importance & $58.4 \%$ & $56.4 \%$ & $53.3 \%$ & $76.8 \%$ & $78.2 \%$ & $68.8 \%$ & $73 \%$ & $54 \%$ & $76.6 \%$ & $81.1 \%$ \\
\hline Satisfaction & $56.8 \%$ & $54 \%$ & $53.5 \%$ & $62.9 \%$ & $64.5 \%$ & $45.7 \%$ & $46.2 \%$ & $50.9 \%$ & $56.6 \%$ & $59.6 \%$ \\
\hline \multicolumn{11}{|l|}{$\begin{array}{l}\text { Integrated work } \\
\text { experience }\end{array}$} \\
\hline Importance & $43 \%$ & $54.2 \%$ & $61.5 \%$ & $61.1 \%$ & $63.3 \%$ & $59.9 \%$ & $63.3 \%$ & $57.5 \%$ & $69 \%$ & $71.7 \%$ \\
\hline Satisfaction & $49.8 \%$ & $69.6 \%$ & $67.7 \%$ & $49.1 \%$ & $51.6 \%$ & $47.2 \%$ & $70.6 \%$ & $68.4 \%$ & $40.9 \%$ & $51.5 \%$ \\
\hline
\end{tabular}




\begin{tabular}{|c|c|c|c|c|c|c|c|c|c|c|}
\hline \begin{tabular}{|l} 
Exchange programs, \\
university \\
partnership \\
(international \\
competences)
\end{tabular} & & & & & & & & & & \\
\hline Importance & $46.2 \%$ & $44.1 \%$ & $47.9 \%$ & $54.4 \%$ & $55.1 \%$ & $56.8 \%$ & $60 \%$ & $50.6 \%$ & $66.4 \%$ & $68.9 \%$ \\
\hline Satisfaction & $60.2 \%$ & $60.1 \%$ & $63.5 \%$ & $64.8 \%$ & $66.1 \%$ & $57.1 \%$ & $55.3 \%$ & $65.5 \%$ & $66.5 \%$ & $68.8 \%$ \\
\hline \multicolumn{11}{|l|}{ Events } \\
\hline Importance & $39 \%$ & $38.2 \%$ & $41.1 \%$ & $52.8 \%$ & $54.4 \%$ & $45.8 \%$ & $51.1 \%$ & $49.8 \%$ & $65.7 \%$ & $64.2 \%$ \\
\hline Satisfaction & $63.3 \%$ & $65.1 \%$ & $64.4 \%$ & $68.1 \%$ & $69 \%$ & $60.1 \%$ & $59 \%$ & $61.5 \%$ & $62 \%$ & $64.8 \%$ \\
\hline \multicolumn{11}{|l|}{$\begin{array}{l}\text { Consultation } \\
\text { service/ careers } \\
\text { advice, Job exchange }\end{array}$} \\
\hline Importance & $46.1 \%$ & $41.6 \%$ & $45.3 \%$ & $50.2 \%$ & $51.6 \%$ & $45.8 \%$ & $57.2 \%$ & $48.2 \%$ & $63.3 \%$ & $62 \%$ \\
\hline Satisfaction & $36 \%$ & $38.9 \%$ & $42.1 \%$ & $50.6 \%$ & $52.1 \%$ & $60.1 \%$ & $36.3 \%$ & $46.3 \%$ & $40.5 \%$ & $45.1 \%$ \\
\hline \multicolumn{11}{|l|}{ Jobs and career fairs } \\
\hline Importance & $51 \%$ & $48.7 \%$ & $48.1 \%$ & $49.2 \%$ & $50.8 \%$ & $59.3 \%$ & $56.3 \%$ & $43.8 \%$ & $63.2 \%$ & $65.8 \%$ \\
\hline Satisfaction & $69.4 \%$ & $52.7 \%$ & $52.8 \%$ & $56.7 \%$ & $58.3 \%$ & $69.6 \%$ & $43.7 \%$ & $48.5 \%$ & $53.5 \%$ & $60 \%$ \\
\hline
\end{tabular}

The evaluation of the dynamics of academic achievements for international and practical competences as presented in the graphics below shows that students' appreciation for lectures in a foreign language, case studies, guests presentations and universities' research projects with companies increased in the last 2 years. In Romania, the interest for international competences gained from internationalized curricula recorded $61.8 \%$ from respondents' number in the year 2015 and $58.6 \%$ in 2016. In terms of satisfaction, Romanian students are content with the programs in foreign languages that they have attended, their appreciation for foreign language programs increasing from $51.9 \%$ to $54.1 \%$ (Graphic 1). The data also highlights the decrease in the gap between importance and satisfaction of Romanian students' appreciation from $9.9 \%$ in 2015 to $4.5 \%$ in 2016. This shows an improvement in curricula for programs in a foreign language. In other European countries, students also have a positive reaction to international competences gained through curricula content, their appreciation for programs in a foreign language increasing from $47.4 \%$ in 2015 to $49.7 \%$ in 2016.

The data from the graphics below presents the information that reveals the dynamics of practical competences as perceived by students, also in terms of importance vs. satisfaction. Usually, case studies and guest presentations are part of curricula and university projects developed with companies that involve students' participation are part of extracurricular activities.

Graph 2 shows that Romanian students consider very important the curricular activities, $60.2 \%$ of respondents' number in 2015 respectively $61.4 \%$ in 2016, but they also experienced low performance of their universities for these activities, in 2015 only $44.8 \%$ respondents being satisfied with curricula content for practical activities. In the next year, the percentage reached $47.3 \%$ and is lower than the European average, which was $49.9 \%$ in 2016. 


\section{Graphic 1: Students' evaluation for lectures in a foreign}

language

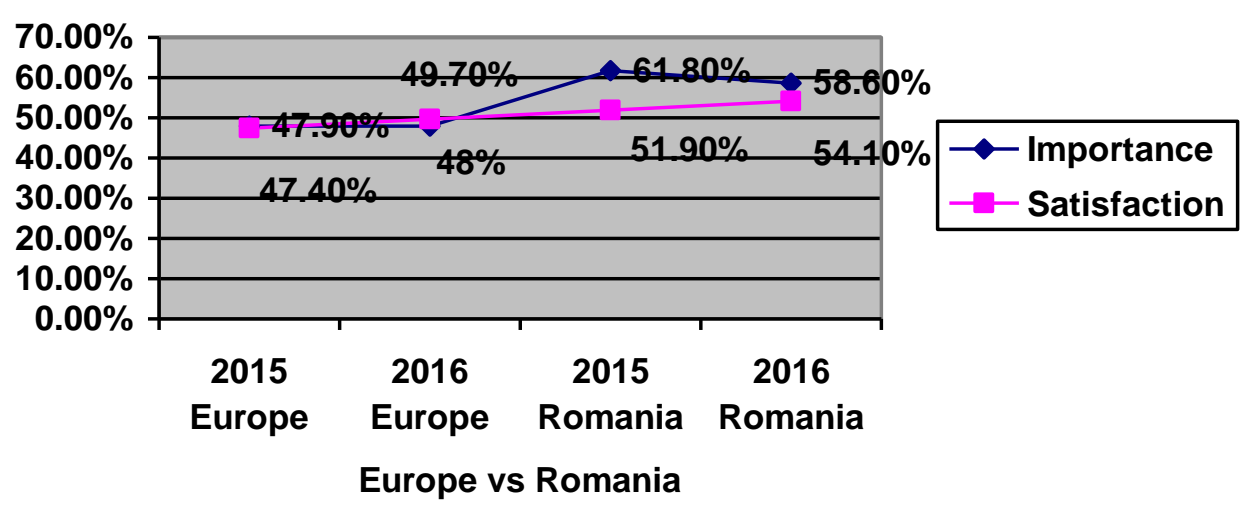

Source: Trendence Graduate Barometer - European edition years 2015, 2016.

Graphic 2: Students' evaluation for case studies and guests presentations

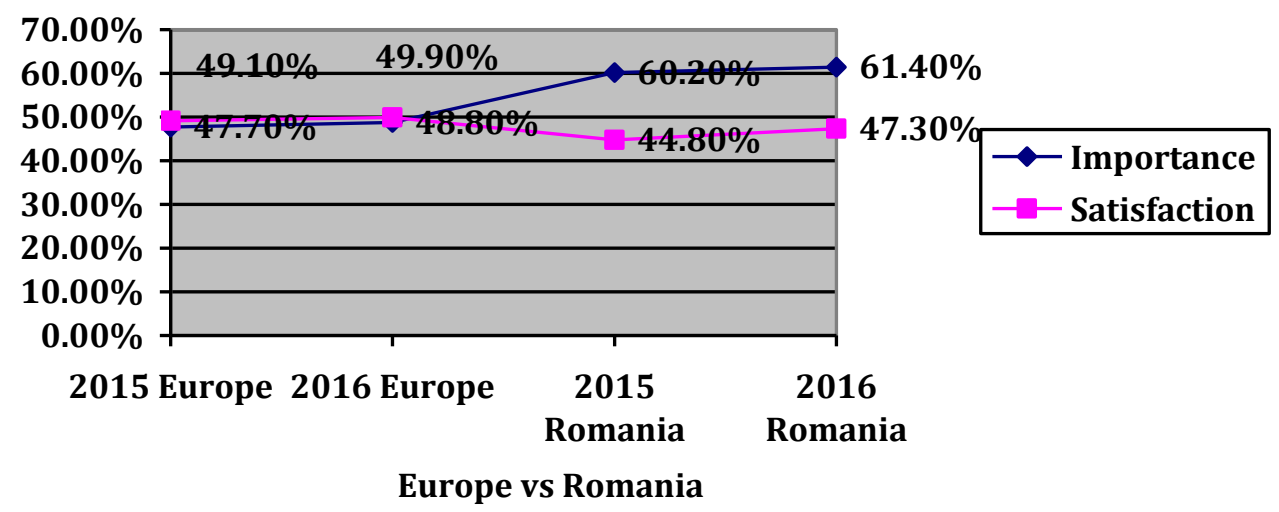

Source: Trendence Graduate Barometer - European edition years 2015, 2016.

The extracurricular activities are also considered very useful for achieving practical competences as will be seen in Graph 3. Thus, in 2016, 63.3\% of Romanian respondents had a positive opinion about achieving practical experience from collaborative projects with companies. In terms of satisfaction with universities' extracurricular activities for research projects, only 48.4\% Romanian students consider that internships are held in high regard. Still, the universities have made some steps for improvement, students' evaluation of university performance for these activities increasing in the last 2 years from $43.8 \%$ to $48.4 \%$. Also, the European students have increased their appreciation in terms of satisfaction for practical extracurricular activities in their universities, in the last 2 years, from $45.7 \%$ in 2015 to $47.5 \%$ in 2016. 
Graphic 3: Students' evaluation for university research projects with companies

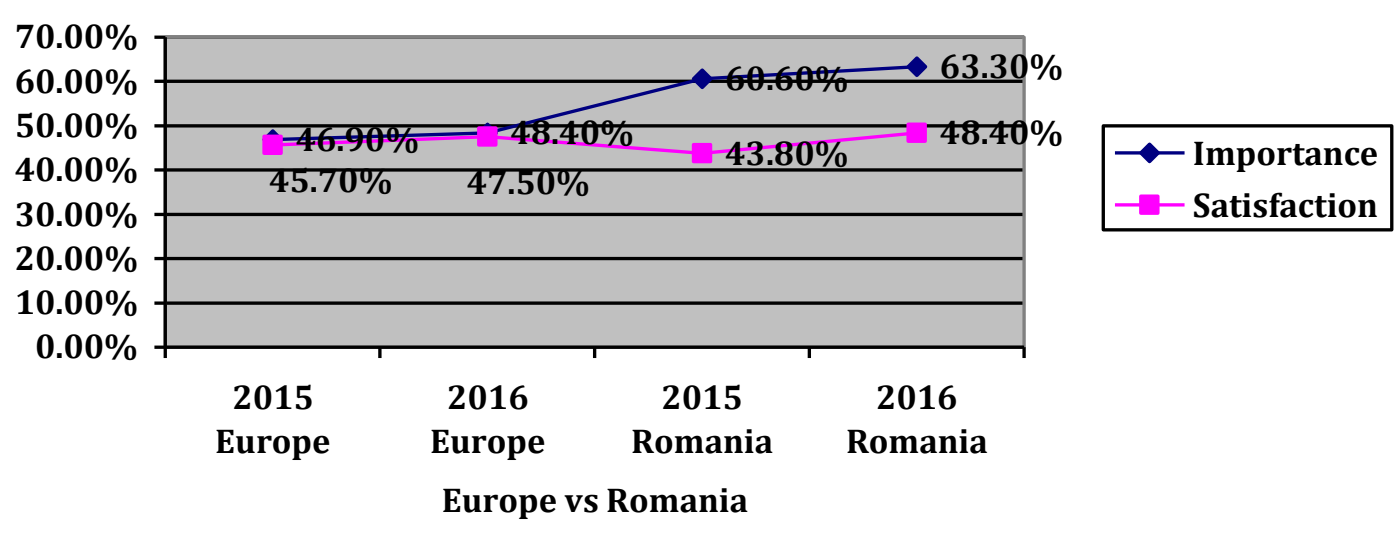

Source: Trendence Graduate Barometer - European edition years 2015, 2016.

\section{Students' appreciation of university performance in terms of interpersonal skills relevant for the labour market}

The dynamics of students' appreciation for interpersonal skills demonstrate an increased recognition for skills that ensure a better absorption of labour market. The data from the Table 4 point out that the European students including Romanians have raised their expectation for achieving useful interpersonal skills such as responsibility, flexibility, ability to work under pressure and social competency. A simple analysis of data presented below could be focused on degree of importance for each interpersonal skill. Thus, from these interpersonal skills, responsibility is considered very important in graduates' future career, followed by flexibility and ability to work under pressure. The appreciation for responsibility from both Romanian and other European students has recorded high values, rising from $45-55 \%$ in 2012 to $86.9 \%-87.5 \%$ in 2016 . The change in work force expectations regarding employee interpersonal skills has increased also the demand for flexibility and ability to work under pressure. Thus, Romanian students have increased their appreciation for these important skills. The development of evaluation for interpersonal skills that ensures efficient work in international environment is also related to their career priorities, as will be seen in Table 5. In Romania, the facts reveal that students' appreciation for flexibility has grown from $75 \%$ in 2012 to $82 \%$ in 2016. Also, the appreciation for the ability to work under pressure has increased from $45 \%$ in 2012 to $83.2 \%$ in 2016. Other European students are less certain to associate a high degree of appreciation for flexibility and ability to work under pressure, the recognition for these skills reaching in 2016 at $78.9 \%$, respectively $66 \%$ of Europeans' respondents. 
Table 4. Students' appreciation for interpersonal skills for the labour market

\begin{tabular}{|l|r|r|r|r|r|r|r|r|r|r|}
\hline $\begin{array}{l}\text { Interpersonal } \\
\text { Skills for the } \\
\text { labour market }\end{array}$ & $\mathbf{2 0 1 2}$ & $\mathbf{2 0 1 3}$ & $\mathbf{2 0 1 4}$ & $\mathbf{2 0 1 5}$ & $\mathbf{2 0 1 6}$ & $\mathbf{2 0 1 2}$ & $\mathbf{2 0 1 3}$ & $\mathbf{2 0 1 4}$ & $\mathbf{2 0 1 5}$ & $\mathbf{2 0 1 6}$ \\
\cline { 2 - 10 } & 45 & $87 \%$ & $87.6 \%$ & $85 \%$ & $86.9 \%$ & $55 \%$ & $87.5 \%$ & $79.6 \%$ & $81.6 \%$ & $87.5 \%$ \\
\hline Responsibility & $70 \%$ & $80.2 \%$ & $78.5 \%$ & $77.8 \%$ & $78.9 \%$ & $75 \%$ & $83.2 \%$ & $77.4 \%$ & $75.8 \%$ & $82 \%$ \\
\hline $\begin{array}{l}\text { Flexibility } \\
\begin{array}{l}\text { Achievement and } \\
\text { aspiration }\end{array}\end{array} \quad 60 \%$ & $50.5 \%$ & $53.7 \%$ & $53 \%$ & $52.1 \%$ & $70 \%$ & $57.5 \%$ & $74.5 \%$ & $74.2 \%$ & $78.7 \%$ \\
\hline $\begin{array}{l}\text { Ability to work } \\
\text { under pressure }\end{array}$ & $45 \%$ & $68.8 \%$ & $65.3 \%$ & $65.3 \%$ & $66 \%$ & $45 \%$ & $76.9 \%$ & $71.1 \%$ & $72,2 \%$ & $83.2 \%$ \\
\hline Social competency & $50 \%$ & $75.7 \%$ & $74.9 \%$ & $75.1 \%$ & $75.5 \%$ & $65 \%$ & $79.7 \%$ & $71.1 \%$ & $71.3 \%$ & $79.9 \%$ \\
\hline
\end{tabular}

\section{The analysis of students' need to develop and career expectation}

The table below shows the dynamics of graduates' career priorities. The data is grouped with conceptual pairings which did not necessarily represent opposites and highlights students' attractiveness for internationally oriented companies and the dynamics of the need for high specialization upon graduation.

Thus, Table 5 provides facts regarding students' need for gaining skills, accomplishing tasks, having permanent or temporary employment and specializing for management or executive position. The data shows that in recent years, Romanian students have tended to accomplish strategic tasks rather than operational tasks. In conjunction with their preference for multinational companies, this could be summarized as a choice for international skills needed for work in high-performing teams. Also, students tend to obtain a permanent job, rather than a temporary one. Analysing the dynamics of these career priorities, the data shows differences from a generation to another. Still, there is a growing tendency to specialize upon graduation, in 2016, more than 52\% of Romanian respondents choosing to follow a trainee programme. In other European countries, students' dynamics for future specialization show an increased interest for specialization (53.9\% in 2013, rising at 54.6\% in 2016) and obtaining a permanent job $(81.6 \%$ in 2016).

Table 5. Students' need to develop for their future career

\begin{tabular}{|l|r|r|r|r|r|r|r|r|}
\hline \multirow{2}{*}{$\begin{array}{l}\text { Career } \\
\text { priorities }\end{array}$} & \multicolumn{4}{|c|}{ Europe } & \multicolumn{3}{|c|}{ Romania } \\
\cline { 2 - 9 } & $\mathbf{2 0 1 3}$ & $\mathbf{2 0 1 4}$ & $\mathbf{2 0 1 5}$ & $\mathbf{2 0 1 6}$ & $\mathbf{2 0 1 3}$ & $\mathbf{2 0 1 4}$ & $\mathbf{2 0 1 5}$ & $\mathbf{2 0 1 6}$ \\
\hline Specializing & $53.9 \%$ & $53.8 \%$ & $54.3 \%$ & $54.6 \%$ & $53.5 \%$ & $56.3 \%$ & $59.3 \%$ & $46.4 \%$ \\
\hline $\begin{array}{l}\text { Gaining } \\
\text { general skills }\end{array}$ & $46.1 \%$ & $46.2 \%$ & $45,70 \%$ & $45.4 \%$ & $46.5 \%$ & $43.7 \%$ & $40.7 \%$ & $53.6 \%$ \\
\hline $\begin{array}{l}\text { Graduate } \\
\text { trainee } \\
\text { programmes }\end{array}$ & $51.9 \%$ & $49.1 \%$ & $48.6 \%$ & $48.9 \%$ & $62.5 \%$ & $56 \%$ & $52.9 \%$ & $61.5 \%$ \\
\hline \begin{tabular}{l} 
Direct entry \\
\hline
\end{tabular} & $48.1 \%$ & $50.9 \%$ & $51.4 \%$ & $51.1 \%$ & $37.5 \%$ & $43.9 \%$ & $47 \%$ & $38.5 \%$ \\
\hline
\end{tabular}




\begin{tabular}{|c|c|c|c|c|c|c|c|c|}
\hline Strategic tasks & $55.3 \%$ & $52.8 \%$ & $52.6 \%$ & $53.8 \%$ & $50.1 \%$ & $51.6 \%$ & $61.2 \%$ & $51 \%$ \\
\hline $\begin{array}{l}\text { Operational } \\
\text { tasks }\end{array}$ & $44.7 \%$ & $47.1 \%$ & $47.4 \%$ & $46.2 \%$ & $49.9 \%$ & $48.4 \%$ & $38.8 \%$ & $49 \%$ \\
\hline $\begin{array}{l}\text { Temporary } \\
\text { employment }\end{array}$ & $15.4 \%$ & $18.4 \%$ & $17.9 \%$ & $18.4 \%$ & $13.6 \%$ & $20 \%$ & $18.8 \%$ & $16.1 \%$ \\
\hline $\begin{array}{l}\text { Permanent } \\
\text { employment }\end{array}$ & $84.6 \%$ & $81.6 \%$ & $82.1 \%$ & $81.6 \%$ & $86.4 \%$ & $80 \%$ & $81.2 \%$ & $83.9 \%$ \\
\hline $\begin{array}{l}\text { Multinational } \\
\text { companies }\end{array}$ & $58 \%$ & $53.2 \%$ & $53.7 \%$ & $53.8 \%$ & $50.8 \%$ & $54.7 \%$ & $56.9 \%$ & $57.2 \%$ \\
\hline $\begin{array}{l}\text { Small/ } \\
\text { medium-sized } \\
\text { enterprise }\end{array}$ & $42 \%$ & $46.7 \%$ & $46.3 \%$ & $46.2 \%$ & $49.2 \%$ & $45.2 \%$ & $43.1 \%$ & $42.8 \%$ \\
\hline $\begin{array}{l}\text { Specialist } \\
\text { position }\end{array}$ & $56.4 \%$ & $57.7 \%$ & $55.3 \%$ & $55.6 \%$ & $56.9 \%$ & $53.8 \%$ & $47.5 \%$ & $59.4 \%$ \\
\hline $\begin{array}{l}\text { General } \\
\text { management } \\
\text { responsibilities }\end{array}$ & $43.6 \%$ & $42.4 \%$ & $44.6 \%$ & $44.4 \%$ & $43.2 \%$ & $46.2 \%$ & $52.5 \%$ & $40.6 \%$ \\
\hline
\end{tabular}

Source: Trendence Graduate Barometer - European edition years 2013, 2014, 2015, 2016.

\section{Conclusions}

Students' appreciation for international experience and international competences has grown in recent years, due to graduates' preference for international companies, in 2016 more than $57 \%$ of Romanian respondents choosing to find a job in a multinational company rather than a small/ medium sized enterprise. The change in students' perception regarding career opportunities and the need for gaining relevant skills is a direct consequence of labour force changing demands that are more related to international and practical experience. Also, the interpersonal skills are considered very useful in finding a job because they ensure efficient work in international environment (more than $87 \%$ of Romanian respondents finding that Responsibility, respectively $82 \%$ that Flexibility are essential for finding a job upon graduation).

The review of appreciation for practical competences revealed that there is a gap between the importance and satisfaction in students' view for this skill as provided by their university. Still there is an improvement in appreciation for practical skills gained during international programs, in 2016, in Romania more than $68.8 \%$ of students being content with their international experience for providing interpersonal and practical skills. The capacity to work under pressure, to adapt in complex and multidisciplinary teams and the social competency are thus 
considered very useful and they are associated with students' preference for internationally oriented companies in their future career.

The evaluation of students' need to develop upon graduation showed that Romanian students want to follow trainee programs in order to gain more specialization for their job. A possible cause for high specialization could be associated with students' preference for accomplishing strategic tasks $(51 \%$ in 2016), rather than operational tasks (38.8\% in 2015).

The internationalized curriculum is also a key factor that ensures gaining international competences. The ability to communicate in more than one language and the capacity to analyse and think critically in order to take a decision according to everyday work issues in multinational companies are among the abilities related to global competences (OECD, 2016). Students' appreciation for internationalized curricula has increased in the late years, more than 58\% Romanian respondents considering that programs in foreign language will help them in their future career.

The frequent changes in curricular and extracurricular activities in Romanian universities are seen in the dynamics of Romanian students' opinion regarding university performance. The data presented above shows that in other European countries there is no significant change in students' appreciation of university performance from one year to another (less than 10\%). An example of large variation in Romanian students' opinion in the last 5 years could be seen in their appreciation for integrated work experience related to voluntary activities provided from extracurricular activities and other universities projects in collaboration with companies (in terms of satisfaction the variation is between $47.2 \%$ to $70.6 \%$ ). A future study on students' employability policy in universities could bring more information regarding policy sustainability and university performance. Also, additional services centred on career advice and other events and projects developed in universities for helping the graduates find a job could represent a basis for a future investigation on university performance. In addition, a future investigation on graduates' decision to continue their studies in the home country or abroad will bring more information regarding their need for specialization and the aspiration for work in an international environment.

\section{References}

Altbach P.G. and Knight, J., (2007), "The internationalization of higher education: Motivations and realities", Journal Studies in International Education, Vol. 11, No. 3/4, pp. 290-305.

Fantini, A.E., (2000), “A central concern: Developing intercultural competence”, SIT Occasional Paper Series Addressing Intercultural Education, Training and Service, Brattleboro: School for International Training, pp. 25-33.

European Commission (2015), Erasmus facts, figures and trends. The European Union support for student and staff exchanges and university cooperation in 20132014, retrieved from ec.europa.eu/dgs/education_culture/repository/ education/library/statistics/erasmus-plus-facts-figures_en.pdf (accessed January 15, 2017). 
European Commission (2013), Press release database, retrieved from europa.eu/rapid/press-release_IP-13-657_ro.htm, (accessed January 15, 2017).

Frunzaru, V. (2013), Învăţământul universitar din România. Dialog cu elevi, studenţi şi profesori, Comunicare.ro, Bucharest.

Găitănaru A., (2016), "Behavioral cognitive patterns within the virtual environment", Euromentor Journal Studies about Education, Vol. 7, No. 1, pp. 14-20.

Government Decision no. 402/2016 concerning accredited master programs and the maximum number of enrolled students in academic year 2016-2017 in Romanian universities, Published in MO, Part I No. 453 from June 16, 2016

Knight, J. (2004), "Internationalization remodeled: Definition, approaches, and rationales", Journal of Studies in International Education, Vol. 8, No. 1, pp. 531.

Matthews, N., Green, P., Hall, D. and Hall I. (2009), "The role of volunteering in transitions from higher education to work", In Brooks, R. (ed.), Transitions from education to work new perspectives from Europe and beyond, pp. 150166, Palgrave Macmillan, Basingstoke.

Nicolescu, L. (2014), "Convergence and Internationalization of Higher Education in Europe: The Case of Romania", in Dima A. M. ed., Handbook of Research and Trends in European Higher Education Convergence, pp. 219-240, IGI Global

Nicolescu L. (2011) "Student experience in Romanian higher education - a comparative institutional approach", Transformations in Business and Economics, Vol. 10, No. 2B, pp. 664-684.

Nicolescu, L. and Dima, A.M., (2010), "The quality of educational services institutional case study from Romanian higher education", Transylvanian Review of Administrative Sciences, No 29E, pp. 100-108.

Nicolescu, L. and Paun C., (2009), "Relating higher education with the labour market: Graduates' expectations and employers' requirements", Tertiary Education and Management, Vol, 15, No. 1, pp. 17-33.

OECD (2016), Global competency for an inclusive world, retrieved from https://www.oecd.org/pisa/aboutpisa/Global-competency-for-an-inclusiveworld.pdf (accessed November 29, 2016).

Qiang, Z. (2003), "Internationalization of higher education: towards a conceptual framework", Policy Futures in Education, Vol. 1, No. 2, pp. 248-270.

Rizvi, F. (2007), "Internationalization of curriculum: A critical perspective", in Hayden, M., Levy, J., and Thompson, J. (eds.) The SAGE Handbook of Research in International Education, pp. 390-402, SAGE Publications, London.

Sawyer W.C. and Sprinkle, R.L. (2003), International economics, Pearson Education, New Jersey.

Teichler U. and Janson K., (2007), "The professional value of temporary study in another European Country: Employment and work of former ERASMUS students", Journal of Studies in International education, Vol. 11, No. 3/4, pp. 486-495. 
The Bucharest University of Economic Studies (2015), Internationalization Strategy 2015-2020, retrieved from iemu.forhe.ro/wp-content/uploads/2015/09/ASE -International-strategy.pdf, (accessed February 10, 2017)

Trendence Graduate Barometer - Romanian edition year 2012 retrieved from www.usv.ro/fisiere_utilizator/file/anunturi/2013/!\%20trendence\%20Grad uate\%20Barometer\%202012_Romanian\%20Edition.ppt (accessed November 15, 2016).

Trendence Graduate Barometer - European edition year 2013 retrieved from web.rau.ro/mydocuments/asociatiaabsolventilorura/2013-trendence\%20 Graduate\%20Barometer\%202013\%20-\%20Romanian\%20Total\%20Edition _URA.pdf (accessed November 15, 2016).

Trendence Graduate Barometer - European edition year 2014 retrieved from qa.ubbcluj.ro/documents/satisfactia_studentilor/esb_2014/Graduate_Barom eter_2014_Romanian_Total_Edition.pdf (accessed November 15, 2016).

Trendence Graduate Barometer - European edition year 2015, in ppt format accessed from National University of Political Studies and Public Administration in July 31, 2015.

Trendence Graduate Barometer - European edition year 2016, retrieved from web.rau.ro/mydocuments/asociatiaabsolventilorura/2016tGRAD16_RO_Total_URA.pdf, (accessed February 10, 2017).

Udrea, G. and Ștefăniță, O. (2016), "Mobility and youth employment in the EU. Addressing students' perspectives about future careers abroad", Responsible entrepreneurship - vision, development and ethics: Proceedings of the 9th International Conference for Entrepreneurship, Innovation and Regional Development, June 23-24, Bucharest, Romania, pp. 413-424, Comunicare.ro. Bucharest.

Van der Wende, M. (1997), "Internationalising the curriculum in Dutch higher education: An international comparative perspective", Journals of Studies in International Education, Vol. 1, No. 2, pp. 56-57. 